\title{
Optimasi Keuntungan Industri Rumah Tangga Tahu dan Tempe Di Desa Murung Kupang Kecamatan Babirik Kabupaten Hulu Sungai Utara
}

\section{(Advantage Optimization of Tofu and Tempeh Household Industry In Murung Kupang Village Babirik District Hulu Sungai Utara Regency)}

\author{
Azwar Saihani $^{1)}$ \& Megawati $^{2)}$ \\ Program Studi Agribisnis, Sekolah Tinggi Ilmu Pertanian Amuntai \\ ${ }^{1)}$ Azwar.saihani63@yahoo.com \\ ${ }^{2)}$ megawati@yahoo.com
}

\begin{abstract}
ABSTRAK
Penelitian ini bertujuan untuk (i) mengetahui keuntungan optimal dari usaha pembuatan tahu dan tempe dengan keterbatasan sumberdaya, (ii) melakukan analisis sensitifitas terhadap kondisi optimal keuntungan usaha tahu dan tempe. Penelitian ini dilakukan di Desa Murung Kupang Kecamatan Babirik Kabupaten Hulu Sungai Utara. Metode pengumpulan data menggunakan studi kasus dengan wawancara kepada Pak Sarwani untuk mendapatkan data yang diperlukan. Titik solusi optimal industri rumah tangga dan tahu terjadi pada koordinat $\{(29,66),(357,47)\}$, ini berarti bahwa manfaat optimal terjadi ketika produksi tahu $\left(X_{1}\right)$ sebanyak 29,66 cetakan tahu dan $\left(X_{2}\right)$ sebanyak 357,47 tempe potong setiap kali produk. Sedangkan jumlah keuntungan optimal yang diperoleh adalah USD 1357.941 setiap satu produksi dalam satu hari. Batas maksimum dan minimum optimasi industri tahu tempe dan tempe. Batas maksimum margin keuntungan keluar antara 43.819 hingga 27.200 dan margin keuntungan batas minimum antara 70.317 hingga 43.819, sedangkan batas maksimum margin keuntungan tempe yang belum digunakan adalah antara 911.222 hingga 567.850, batas minimum tempe margin keuntungan antara 1.468 hingga 911.222, dan di fungsi kendala nilai terjemahan bayangan 1 (kedelai) tampak bahwa jika sumber daya (nilai kanan) melebihi fungsi kendala 10\% yaitu dari 102663 933,33 menjadi nilai optimal Rp 161.261 meningkat dari $R p$ 1.357.941 menjadi $R p$ 1.519.202.
\end{abstract}

Kata kunci: Pemrograman linier, analisis sensitivitas, tahu, tempe.

\section{ABSTRACT}

This study aims to (i) know the optimal benefits of tofu and tempeh making business with limited resources, (ii) conduct sensitivity analysis on the optimal conditions of the benefits of tofu and tempeh business. This research was conducted in Murung Kupang Village, Babirik District, North Hulu Sungai Regency. The method of collecting data uses a case study by interviewing Pak Sarwani to obtain the necessary data. The point of optimal home industry and tofu solutions occurs at coordinates $\{(29.66)$, (357.47)\}, this means that optimal benefits occur when production of tofu $\left(X_{I}\right)$ is 29.66 prints of tofu and $\left(X_{2}\right)$ of 357, 47 tempe cut each time the product. While the optimal amount of profit obtained is USD 1357,941 per one production in one day. Maximum and minimum limit for optimization of tempe and tempeh tofu industry. The maximum profit margin exits between 43,819 to 27,200 and the minimum margin of profit margin between 70,317 to 43,819, while the maximum limit of profit margin for tempe that has not been used is between 911,222 to 567,850, the minimum tempe profit margin between 1,468 to 911,222 , and the translation value constraint function shadow 1 (soybeans) it appears that if the resource (right value) exceeds the 10\% constraint function, ie from 102663933.33 to the optimal value of Rp 161,261, increasing from $R p$ 1,357,941 to $R p$ 1,519,202.

Keywords: Linear programming, sensitivity analysis, tofu, tempeh.

\section{PENDAHULUAN}

Kedelai dikenal paling rendah
kandungan racun kimia serta residu

pestisidanya. Kedelai banyak dikonsumsi sebagai salah satu alternatif untuk menggantikan protein hewan yang relatif lebih mahal. Adapun manfaat dari kacang 
kedelai adalah sebagai antioksidan, mengurangi resiko penyakit jantung, mencegah kanker, mengatasi gejala menopause, memberi efek baik untuk diabetes dan sakit ginjal, dan menjaga berat badan. Khasiat dari kacang kedelai lainnya adalah menghaluskan kulit, membuatnya bercahaya dan segar, mengurangi potensi penuaan dini, dan menyuburkan rambut (Cahyadi, 2012). Hasil olahan kedelai diantaranya adalah tahu dan tempe. Tempe merupakan makanan khas indonesia, tempe tidak hanya disukai rakyat di negeri kita saja, di luar negeripun penggemar tempe sudah berkembang, terutama di Jepang, Amerika Serikat dan Negara negara Eropa. Kebutuhan tempe di negara tersebut semakin lama semakin meningkat, karena sebagian orang mulai merasakan betapa terbatas dan mahalnya bahan sumber protein hewani. Secara ekonomis harga tempe lebih murah dari pada daging sementara protein tempe dapat dijadikan alternatif pengganti dari protein daging (Astawan, 2003).

Indonesia merupakan negara produsen tempe terbesar di dunia dan menjadi pasar kedelai terbesar di Asia. Sebanyak 50\% dari konsumsi kedelai Indonesia dilakukan dalam bentuk tempe, $40 \%$ tahu, dan $10 \%$ dalam bentuk produk lain (seperti tauco dan kecap), dan Konsumsi tempe rata-rata per orang per tahun di Indonesia saat ini diduga sekitar $6,45 \mathrm{~kg}$ (Astawan, 2003).

Industri adalah suatu usaha atau kegiatan pengolahan bahan mentah atau barang setengah jadi menjadi barang jadi barang jadi yang memiliki nilai tambah untuk mendapatkan keuntungan. Kabupaten Hulu Sungai Utara memiliki ada beberapa macam industri yang telah diusahakan, berikut adalah menurut kelompok industri dapat dilihat pada Tabel 1.

Tabel 1. Jumlah perusahaan industri besar dan sedang dan jumlah tenaga kerja Kabupaten Hulu Sungai Utara.

\begin{tabular}{cccc}
\hline No & Tahun & Jumlah Perusahaan & Jumlah Tenaga Kerja (Orang) \\
\hline 1 & 2007 & 9 & 435 \\
2 & 2008 & 7 & 348 \\
3 & 2009 & 6 & 492 \\
4 & 2010 & 6 & 320 \\
5 & 2011 & 6 & 286 \\
\hline
\end{tabular}

Sumber: Dinas Perindustrian, Koperasi dan Perdagangan Kabupaten HSU (2014).

Di Kabupaten Hulu Sungai Utara tidak semua kecamatan memiliki usaha industri rumah tangga, tetapi hanya sebagian kecamatan saja salah satunya terdapat pada Kecamatan Babirik dimana terdapat satu industri kecil ialah industri rumah tangga tahu dan tempe milik Bapak Sarwani yang terdapat di Desa Murung Kupang. Industri rumah tangga ini sudah berjalan 10 tahun yaitu dari tahun 2004-2015. Keuntungan usaha yang diperoleh setiap tahunnya meningkat sehingga usaha industri rumah tangga bapak Sarwani sangat menjanjikan untuk dijalankan, tetapi pengusaha tahu dan tempe sekarang ini menghadapi masalah harga bahan baku turun naik tak menentu, ketersedian bahan baku terkadang sulit didapat (langka). Hal ini bisa mengakibatkan kemungkinan keuntungan usaha menjadi turun dan bahkan bisa menjadi bangkrut.

Tujuan penelitian (i) mengetahui keuntungan optimal dari usaha pembuatan tahu dan tempe dengan keterbatasan sumberdaya, (ii) melakukan analisis sensitifitas terhadap kondisi optimal keuntungan usaha tahu dan tempe. 


\section{METODE PENELITIAN}

\section{Tempat dan Waktu Penelitian}

Penelitian ini dilaksanakan pada usaha milik Bapak Sarwani di Desa Murung Kupang Kecamatan Babirik Kabupaten Hulu Sungai Utara dimulai pada bulan Februari sampai Mei 2015.

\section{Metode Pengumpulan Data}

Penelitian ini merupakan studi kasus pada industri rumah tangga tahu dan tempe milik bapak Sarwani. Untuk mendapatkan data yang diperlukan yaitu berupa data biaya produksi, harga jual produk, jumlah maksimal produk yang dibuat, dan lama produksi didapat dari dengan wawancara responden.

\section{Analisis Data}

Analisis data dgunakan untuk memperoleh informasi tentanag pecahan optimum yang baru dan yang dimungkinkan (yang bersesuai dengan perubahan parameter tersebut) dengan perhitungan tambahan yang minimal. Analisis sensitivitas terutama sangat sesuai untuk pengaruh variasi dalam koefisin biaya/laba dan dalam jumlah sumber daya yang tersedia terhadap pemecahan optimum (Taha, 1993).

Masalah seensitivitas adalah berapa besar perubahan yang diijinkan dalam koefisin fungsi tujuan optimasi tentang usaha ini Perubahan dalam koefisin hanya akan memepelajari kemiringan garis lurus yang diwakili olehnya. Analisis sensitivitas disini menentukan kisaran variasi dalam setiap koefisin fungsi tujuan yang akan membuat titik sudut optimum ini tetap tidak berubah (Taha, 1993).

\section{HASIL DAN PEMBAHASAN}

\section{Optimasi Keuntungan Industri rumah tangga tahu dan tempe}

Hasil analisis yang dilakukan dengan metode pemprograman linier, maka fungsi tujuan dan fungsi kendala harus berbentuk pertidaksamaan linier. Pertidaksamaan linier optimasi keuntungan usaha industri rumah tangga tahu dan tempe dimodelkan dalam Tabel 2 berikut :

Tabel 2. Model pertidaksamaan linier optimasi keuntungan industri rumah tangga tahu dan tempe.

\begin{tabular}{|c|c|c|c|}
\hline \multirow{2}{*}{ Input $\quad$ Produksi } & \multicolumn{2}{|c|}{ Jenis Produk } & \multirow{2}{*}{ Input yang tersedia } \\
\hline & Tahu $\left(\mathrm{X}_{1}\right)$ & Tempe $\left(\mathrm{X}_{2}\right)$ & \\
\hline Kacang Kedelai & 2 & 0,067 & $93,33 \mathrm{Kg}$ \\
\hline Air & 8 & 0.167 & $300 \mathrm{Lt}$ \\
\hline Kayu Bakar & 3,2 & 0,067 & 200 Bilah \\
\hline Waktu & 0,24 & 0,013 & $12 \mathrm{Jam}$ \\
\hline Keuntungan (Z) & 27.200 & 1.468 & ...... \\
\hline
\end{tabular}

Berdasarkan tabel di atas, maka terbentuklah sebuah fungsi tujuan dan fungsi kendala :

Fungsi tujuan (maksimisasi)

$\mathrm{Z}=27.200 \mathrm{X}_{1}+1.468 \mathrm{X}_{2}$

Fungsi Kendala :

$2 X_{1}+0,067 X_{2} \leq 93,33$

$8 \mathrm{X}_{1}+0,167 \mathrm{X}_{2} \leq 300$

$3,2 X_{1}+0,067 X_{2} \leq 200$

$0,24 X_{1}+0,013 X_{2} \leq 12$

$\mathrm{X}_{1}$ dan $\mathrm{X}_{2} \geq 0$
Koefisien fungsi tujuan yang digunakan dalam penelitian ini adalah keuntungan (Rp) produk tahu tiap satu cetakkan dan keuntungan produk tempe tiap satu cetakkan tempe yang diproduksi. Fungsi tujuan dimana $\mathrm{Z}$ keuntungan dari 2 jenis produk untuk $\mathrm{X}_{1}$ adalah Tahu dan $\mathrm{X}_{2}$ adalah Tempe. Keuntungan yang dimaksud fungsi tujuan adalah dimana hasil biaya produksi untuk masing-masing dijumlahkan dan hasil dari penjualan biaya masingmasing tersebut dikurangkan dengan hasi 
jual untuk masing-masing jenis. Sehingga dapat menghasilkan keuntungan atau $\mathrm{Z}$ untuk $X_{1}$ Rp 27.200,- sedangkan $X_{2}$ Rp 1.468-,. Sedangkan untuk fungsi kendala dimana kendalai 1 kebutuhan kebutuhan bahan baku kacang kedelai dengan satuan $\mathrm{Kg}$, kendala 2 kebutuhan bahan baku air dengan satuan liter, kendala 3 kebutuhan bahan baku kayu dengan satuan bilah dan kendala 4 kebutuhan waktu dengan satuan jam.

\section{Pemrograman Linier Metode Grafik}

Merumuskan optimasi keuntungan usaha Tahu dan Tempe dengan pemrograman linier dengan cara metode grafik. Untuk penyelesaikan persoalan dengan metode grafik maka pertidaksamaan optimasi keuntungan Industri rumah tangga tahu dan tempe dapat dibuat dengan perfotongan masing-masing garis dengan sumbu $X_{1}$ dan $X_{2}$. Setelah menentukan perfotongan masing-masing garis dengan sumbu X1 dan X2 yaitu dari kendala sebelumnya, contoh pada kendala 1 dimna $2 X_{1}+0,067 X_{2} \leq 93,33$ Jika $X_{1}=0$, maka 2 (0) $+0,067 \mathrm{X}_{2}=933,33$ dibagi $0,067=$ 1.392.985 dan seterusnya sampai dengan kendala 4. Setelah itu dapat digambarkan grafik pada penyelesaian persoalan optimasi keuntungan industri rumah tangga tahu dan tempe dengan metode pemprograman linier. Hasil penghitungan dapat dilihat pada Gambar 1 berikut ini.

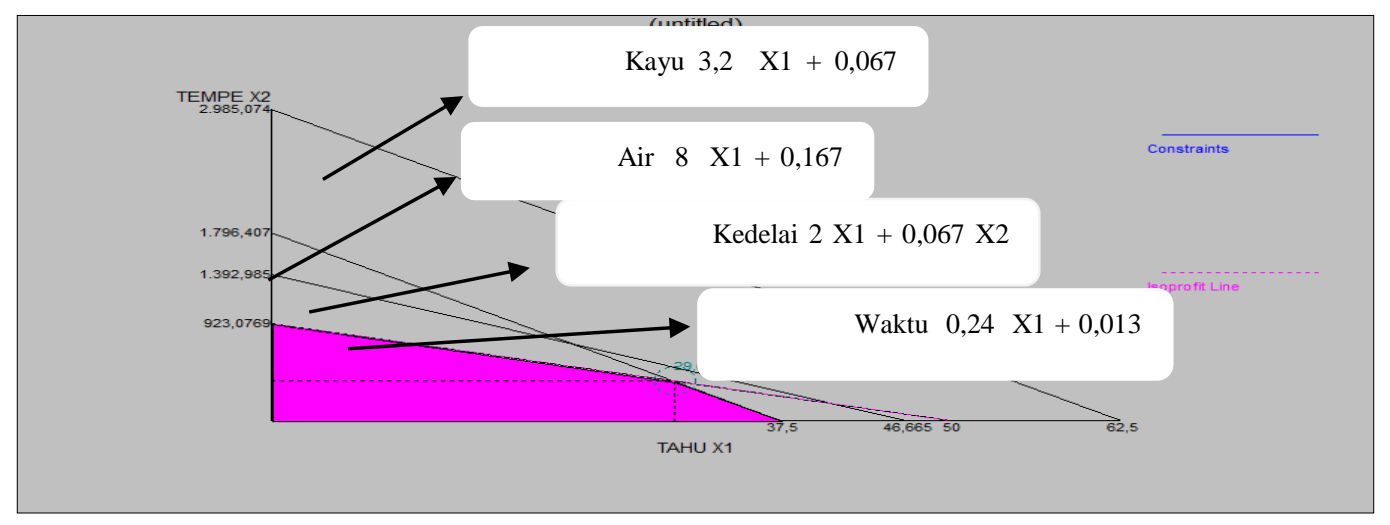

Gambar 1. Grafik optimasi keuntungan industri rumah tangga tahu dan tempe

Grafik di atas menunjukan bahwa titik solusi optimum terjadi pada koordinat $\{(29,66)\},\{(375,47\})$ dan jumlah keuntungan optimum dapat diketahui sebagai berikut :

$$
\begin{aligned}
\mathrm{Z} & =\operatorname{Rp} 27.200 \mathrm{X}_{1}+\mathrm{Rp} 1.468 \mathrm{X}_{2} \\
& =\operatorname{Rp} 27.200(29,66)+\operatorname{Rp~} 1.468 \\
(375,47) & \\
& =\operatorname{Rp} 806.752+\operatorname{Rp} 551.189 \\
\mathrm{Z} & =\operatorname{Rp} 1.357 .941 \\
& \text { Jadi untuk mendapat keuntungan }
\end{aligned}
$$
dengan rata-rata keterbatasan sumberdaya yang tersedia, pengusaha industri rumah tangga tahu dan tempe sebaiknya memproduksi tahu sebanyak 29,66 cetakan tiap kali produksi dan untuk tempe sebanyak 375,47 keping setiap akali produksi, sehingga akan diperoleh nilai keuntungan optimal Rp 1.357,941 perhari.
Industri rumah tangga milik bapak Sarwani ini memproduksi tahu dan tempe setiap hari, kegiatan barjalan 29-30 hari dalam 1 bulan. Berdasarkan hasil penghitungan yang penulis lakukan, pengusaha industri rumah tangga tahu dan tempe milik Bapak Sarwani sebaiknya memproduksi tahu sebanyak 29,66 cetakkan perhari dan untuk tempe 375,47 keping setiap kali produksi, dilihat dari keuntungan optimum yang diperoleh yaitu sebesar $\mathrm{Rp}$ $1.357,941$ setiap kali produksi perhari. Maka keuntungan yang diperoleh selama satu bulan adalah sebesar Rp 40.738,23 jadi penghasilan yang diperoleh selama setahun mencapai Rp 488.858,76. Keuntungan yang dicapai, usaha seperti industri rumah tangga tahu dan tempe ini cukup menjanjikan untuk di usahakn, Jadi jika 
penulis ataupun pembaca ingin membuka usaha, tidak ada salahnya mencoba usaha industri rumah tangga tahu dan tempe.

\section{Analisis Sensitifitas Metode Grafik}

Analisis sensitifitas merupakan suatu cara untuk mengetahui pengaruh pada solusi optimal yang dihasilkan oleh metode grafik jika parameter diubah nilainya. Manfaat utama dari analisis sensitifitas adalah mengidentifikasi parameter yang sensitif (parameter yang mengubah solusi optimal bila nilainya diubah). Juga untuk menghindari pengulangan perhitungan dari awal, apabila terjadi perubahan-perubahan pada masalah pemprograman linier.
Analisis Koefisien Fungsi Tujuan

Koefisien fungsi tujuan adalah besarnya kontribusi keuntungan setiap variabel keputusan. Jadi untuk fungsi tujuan maksimisasi, semakin besar koefisien suatu variabel keputusan, semakin besar pula kontribusi keuntungan yang diberikan oleh variabel keputusan tersebut.

Perubahan koefisien variabel keputusan adalah jika koefisien fungsi tujuan untuk maksimisasi atau keuntungan naik satu koefisien saja, maka sampai batasbatas tertentu tidak perlu menghitung ulang untuk seluruh formulasi (Bustami, 2005).

Tabel 3. Batas-Batas Maksimum Dan Minimum Optimasi Keuntungan Industri Rumah Tangga Tahu Dan Tempe.

\begin{tabular}{lcc}
\hline \multicolumn{1}{c}{ Keuntungan } & Batas Maksimum & Batas Minimum \\
\hline Margin (Keuntungan Tahu) & $43.819 \leq \mathrm{C}_{1} \leq 27.200$ & $70.317 \geq \mathrm{C}_{1} \geq 43.819$ \\
Margin (Keuntungan Tempe) & $911.222 \geq \mathrm{C}_{2} \geq 567.850$ & $1.468 \leq \mathrm{C}_{2} \leq 911.222$ \\
\hline
\end{tabular}

Batas maksimum dan batas minimum tersebut tidak perlu menghitung ulang untuk seluruh formasi. Jadi selama fungsi tujuan berada dalam batas tersebut, maka variabel keputusannya tidak berubah yaitu tetap 29,66 cetakkan tahu dan 375,47 keping tempe, yang berubah hanya nilai optimalnya.

\begin{abstract}
Analisis Sumber Daya dan Shadow Value
Shadow Value adalah nilai yang menunjukkan peningkatan keuntungan yang diperoleh dari penambahan setiap unit input (sumberdaya) usaha industri rumah tangga tahu dan tempe, yang ditunjukan dengan nilai sama dengan nol.
\end{abstract}

Tabel 4. Perbandingan Hasil Analisis Sumberdaya Dengan Nilai Optimasi Keuntungan Usaha Industri rumah tangga tahu dan tempe.

\begin{tabular}{cccccc}
\hline $\begin{array}{c}\text { Nama } \\
\text { Strata }\end{array}$ & $\begin{array}{c}\text { Jenis Sumbardaya } \\
\text { (Dilebihkan10\%) }\end{array}$ & $\begin{array}{c}\text { Produk } \\
\text { Tahu }\end{array}$ & $\begin{array}{c}\text { Produk } \\
\text { Tempe }\end{array}$ & $\begin{array}{c}\text { Nilai } \\
\text { Optimasi } \\
\text { baru (Rp) }\end{array}$ & $\begin{array}{c}\text { Shadow } \\
\text { Value (Rp) }\end{array}$ \\
\hline Kendala 1 & Kacang Kedelai & 43,933 & 220,862 & $1.519,202$ & 161.261 \\
\hline
\end{tabular}

Berdasarkan tabel diatas, dapat disimpulkan bahwa shadow value fungsi kendala 1 (kacang kedelai) adalah Rp 161.261. Pada penjabaran shadow value fungsi kendala 1 (kacang kedelai) tampak bahwa apabila sumberdaya (nilai kanan) fungsi kendala dilebihkan $10 \%$ yaitu dari 933,33 menjadi 102.663 maka optimal value bertambah Rp 161.261 yaitu dari Rp 1.357.941 menjadi Rp 1.519.202.

Penambahan nilai sumbardaya ini bisa saja kurang atau lebih dari $10 \%$, tergantung keinginan peneliti dilihat dari situasi atau keadaan yang diteliti. Karena analisis shadow value berfungsi sebagai acuan jika perubahan ketersediaan 
sumberdaya atau jika ingin menambah nilai sumbardaya.

\section{KESIMPULAN}

Titik solusi optimum industri rumah tangga tahu dan tempe terjadi pada koordinat $\{(29,66),(357,47)\}$, ini berarti bahwa keuntungan optimum terjadi pada saat produksi tahu (X1) sebanyak 29,66 cetakkan tahu dan (X2) sebanyak 357,47 keping tempe setiap kali produk. Sedangkan jumlah keuntungan optimum yang diperoleh adalah sebesar Rp 1.357,941 setiap satu kali produksi 1 hari. Sedangkan batasan maksimum dan minimum optimasi keuntungan industri rumah tangga tahu dan tempe. Batasan maksimum margin keuntungan tahu antara 43.819 dengan 27.200 dan batasan minimum margin keuntungan tahu antara 70.317 dengan 43.819, sedangkan untunk batasan maksimum margin keuntungan tempe adalah antara 911,222 dengan 567,850, batasan minimum margin keuntungan tempe antara 1.468 dengan 911.222, dan pada penjabaran shadow value fungsi kendala 1 (kacang kedelai) tampak bahwa apabila sumberdaya (nilai kanan) fungsi kendala dilebihkan $10 \%$ yaitu dari 93,33 menjadi 102.663 maka optimal value bertambah $\mathrm{Rp} 161.261$ yaitu dari Rp 1.357.941 menjadi Rp 1.519,202.

\section{DAFTAR PUSTAKA}

Astawan, M. 2003. Tempe: Cegah Penuaan \& Kanker Payudara. Jakarta. Diakses tanggal 13 Februari 2015.

Bustami, H. 2005. Fundamental Operation Research. PT. Gramedia Pustaka Umum. Jakarta

Cahyadi. 2012. Kedelai : Khasiat dan Teknologi. Bumi Aksara. Jakarta.

Dinas Perindustrian, Koperasi dan Perdagangan Kabupaten Hulu Sungai Utara. 2014. Data Idustri Kecil Menengah. Amuntai.

Taha, A. H. 1993. Riset Operasi Jilid 1. Penerbit Binarupa Aksara. Jakarta. 